\title{
Analisis Hubungan Tingkat Kesejahteraan Tanggung Jawab dan Motivasi terhadap Kepuasan Kerja Perawat dan Bidan
}

\author{
Hafsia K. N. Mokodompit, ${ }^{1}$ Lydia E. N. Tendean ${ }^{1}$, Max F. J. Mantik ${ }^{2}$ \\ ${ }^{1}$ Program Studi Magister Ilmu Kesehatan Masyarakat Universitas Sam Ratulangi, Manado, \\ Indonesia \\ ${ }^{2}$ Bagian Biologi Fakultas Kedokteran Universitas Sam Ratulangi, Manado, Indonesia \\ ${ }^{3}$ Bagian Ilmu Kesehatan Anak Fakultas Kedokteran Universitas Sam Ratulangi, Manado, \\ Indonesia \\ Email: hafsiamokodompit92@gmail.com
}

\begin{abstract}
Health worker is everyone who devotes him/herself in the health sector and has knowledge and skills through education in the health sector, such as nurse and midwife. The maximum service of a health worker can be achievd if the level of satisfaction is good. Various factors can affect the satisfaction of nurses and midwives working in an hospital organization, such as welfare, responsibility, and work motivation. This study was aimed to assess the relationship between welfare, responsibility, work motivation and satisfaction among nurses and midwives. This was an analytical, observational, and quantitative study with a cross sectional design. There were 119 health workers of General Hospital GMIBM Monompia Kotamobagu involved in this study consisting of 107 nurses and 12 midwives obtained by using the total sampling method. The multiple linear test showed that the level of welfare affected job satisfaction $(p=0.000)$, while responsibility and motivation did not affect job satisfaction $(p=0.371$ and $\mathrm{p}=0.415$ ). The simultaneous test resulted in an F-value of 6.112 where welfare/income, responsibility, and motivation simultaneously affected the job satisfaction of nurses and midwives. In conclusion, welfare significantly influenced the satisfaction of nurses and midwives meanwhile responsibility and motivation did not.
\end{abstract}

Keywords: level of welfare; responsibility; motivation and job satisfaction

\begin{abstract}
Abstrak: Tenaga kesehatan adalah setiap orang yang mengabdikan diri dalam bidang kesehatan serta memiliki pengetahuan dan keterampilan melalui pendidikan di bidang kesehatan seperti perawat dan bidan. Pemberian pelayanan yang maksimal dari tenaga kesehatan dapat tercapai bila tingkat kepuasan kerja perawat dan bidan baik. Berbagai faktor dapat mempengaruhi kepuasan kerja pada perawat dan bidan dalam suatu organisasi rumah sakit, di antaranya tingkat kesejahteraan, tanggung jawab, dan motivasi kerja. Penelitian ini bertujuan untuk mengetahui hubungan antara tingkat kesejahteraan, tanggung jawab, dan motivasi dengan kepuasan kerja pada perawat dan bidan. Jenis penelitian ialah kuantitatif dan analitik observasional dengan desain potong lintang. Subyek penelitian berjumlah 119 orang tenaga kesehatan Rumah Sakit Umum GMIBM Monompia Kotamobagu, terdiri dari 107 perawat dan 12 bidan diperoleh dengan teknik total sampling. Hasil penelitian uji linear berganda mendapatkan tingkat kesejahteraan memengaruhi kepuasan kerja $(\mathrm{p}=0 ., 00)$, sedangkan tanggung jawab dan motivasi tidak memengaruhi kepuasan kerja $(\mathrm{p}=0,371$ dan $\mathrm{p}=0,415)$. Pada hasil uji simultan didapatkan nilai $\mathrm{F}=6,112$ dimana kesejahteraan/pendapatan, tanggung jawab, dan motivasi secara serempak memengaruhi kepuasan kerja. Simpulan penelitian ini ialah kesejahteraan/pendapatan mempunyai pengaruh bermakna terhadap kepuasan kerja perawat dan bidan sedangkan tanggung jawab dan motivasi tidak mempunyai pengaruh terhadap kepuasan kerja perawat dan bidan.
\end{abstract}

Kata kunci: kesejahteraan; tanggung jawab; motivasi kerja dan kepuasan kerja 


\section{PENDAHULUAN}

Tenaga kesehatan adalah setiap orang yang mengabdikan diri dalam bidang kesehatan serta memiliki pengetahuan dan ketrampilan melalui pendidikan di bidang kesehatan, antara lain perawat dan bidan. ${ }^{1}$ Pemberian pelayanan yang maksimal dari tenaga kesehatan dapat tercapai bila tingkat kepuasan kerja perawat dan bidan baik. Rumah sakit tempat mempekerjakan perawat dan bidan harus menjamin terpenuhinya hak-hak tenaga kesehatan sesuai dengan beban kerja yang diberikan sehingga para tenaga kesehatan dapat memberikan pelayanan yang maksimal. Beban kerja perawat dan bidan dapat berkurang dengan terpenuhinya tingkat kepuasan kerja perawat dan bidan. $^{2}$

Pada dasarnya kepuasan kerja merupakan hal yang bersifat individual karena setiap individu memiliki tingkat kepuasan yang berbeda-beda sesuai dengan nilai-nilai yang berlaku dalam dirinya. Semakin banyak aspek dalam pekerjaan yang sesuai dengan keinginan individu, maka semakin tinggi tingkat kepuasan yang dirasakan. ${ }^{2}$ Tingkat kesejahteraan yang kurang serta lingkungan kerja perawat dan bidan yang tidak kondusif, dapat memengaruhi kinerja organisasi, dalam hal ini kinerja rumah sakit. Menurut Melo et al, ${ }^{3}$ kepuasan kerja adalah perasaan sejahtera yang dihasilkan dari beberapa aspek pekerjaan dan dapat memengaruhi hubungan antara pekerja dengan organisasi, klien, dan keluarga, serta menjadi hal penting untuk kualitas pelayanan keperawatan. $^{3}$

Dampak kepuasan kerja cenderung terpusat pada kinerja karyawan, tingkat kehadiran, serta tingkat keluar masuknya pasien dan karyawan (turnover). ${ }^{4}$ Dengan kata lain kepuasan kerja dapat dipengaruhi oleh rasa tanggung jawab tenaga kesehatan dalam menjalankan setiap tugas dan pekerjaannya. Selain itu kepuasan kerja juga dapat dipengaruhi oleh perasaan seseorang dalam melaksanakan tugasnya; dengan kata lain motivasi kerja yang benar dapat membuat sesorang menjadi lebih semangat dalam bekerja. Menurut Wijono ${ }^{5}$ kepuasan kerja merupakan perasaan senang yang didapatkan dari hasil persepsi individu dalam rangka menyelesaikan tugas atau memenuhi kebutuhannya untuk memperoleh nilai-nilai kerja yang penting bagi dirinya.

Berdasarkan latar belakang yang telah dipaparkan maka penulis terdorong untuk meneliti tenaga kesehatan lebih khusus perawat dan bidan yang bekerja di RSU Gereja Masehi Injili Bolaang Mongondow (GMIBM) Monompia Kotamobagu untuk mendapatkan informasi tentang hubungan tingkat kesejahteraan, tanggung jawab, dan motivasi dengan kepuasan kerja.

\section{METODE PENELITIAN}

Penelitian ini merupakan suatu penelitian kuantitatif yang bersifat analitik observasional dengan desain potong lintang. Populasi ialah seluruh perawat dan bidan di Rumah Sakit Umum GMIBM Monompia Kotamobagu dengan jumlah 119 orang, terdiri dari 107 perawat dan 12 bidan. Pengambilan jumlah sampel menggunakan metode total sampling, dimana seluruh populasi dijadikan sampel yaitu sebanyak 119 tenaga kesehatan. ${ }^{6}$

\section{HASIL PENELITIAN}

Secara kuantitatif populasi yang digunakan pada penelitian ini yaitu tenaga kesehatan perawat dan bidan di RS GMIBM Monopia Kotamobagu. Sampel penelitian ini berjumlah 119 orang yang bersedia untuk menjadi responden.

Tabel 1 memperlihatkan karakteristik responden penelitian. Jenis kelamin perempuan merupakan responden terbanyak yakni berjumlah 110 orang $(92,4 \%)$. Usia para respoden terbanyak ialah dewasa awal (26-35 tahun) berjumlah 84 orang $(70,6 \%)$ yang merupakan usia produktif untuk bekerja. Responden terbanyak memiliki tingkat pendidikan D3 Keperawatan yakni sebanyak 86 orang $(72,3 \%)$. Untuk lama kerja, responden bekerja, terbanyak yaitu di atas 2 tahun berjumlah 85 orang $(71,4 \%)$.

Pada penelitian ini terdapat tiga variabel bebas yaitu kesejahteraan/pendapatan, tanggung jawab, dan motivasi kerja. Selain itu terdapat juga satu variabel terikat yaitu kepuasan kerja. Tabel 2 memperlihatkan 
distribusi responden yang merupakan perawat dan bidan di RSU GMIBM Monompia Kotamobagu berdasarkan variabel kesejahteraan/pendapatan. Sebagian besar responden $(56,3 \%)$ tergolong sejahtera yakni sebanyak 67 orang. Sekitar 52 responden $(43,7 \%)$ menyatakan belum sesuai pendapatan/ kesejahteraan mereka.

Tabel 1. Karakteristik responden penelitian

\begin{tabular}{ll}
\hline \multicolumn{1}{c}{ Variabel } & \multicolumn{1}{c}{$\mathbf{N}(\%)$} \\
\hline Jenis kelamin & $9(7,6)$ \\
Laki-laki & $110(92,4)$ \\
Perempuan & \\
Usia & $29(24,4)$ \\
Remaja akhir (17-25 tahun) & $84(70,6)$ \\
Dewasa awal (26-35 tahun) & $4(3,4)$ \\
Dewasa akhir (36-45 tahun) & $2(1,7)$ \\
Lansia awal (46-55 tahun) & $29(24,4)$ \\
Lansia akhir (56-65 tahun) & \\
Pendidikan & $86(72,3)$ \\
D3 Keperawatan & $21(17,6)$ \\
S.Kep/Ners & $9(7,6)$ \\
D3 Kebidanan & $3(2,5)$ \\
D4 Kebidanan & \\
Lama kerja & $85(71,4)$ \\
$\geq 2$ tahun & $16(13,4)$ \\
4 tahun & $10(8,4$ \\
$>5$ tahun & $5(4,2)$ \\
6-10 tahun & $3(2,5)$ \\
$\geq 10$ tahun & $119(100)$ \\
Total &
\end{tabular}

Tabel 2. Hasil univariat variabel kesejahteraan

\begin{tabular}{lc}
\hline $\begin{array}{c}\text { Kesejahteraan/ } \\
\text { Pendapatan }\end{array}$ & $\mathrm{N}(\%)$ \\
\hline Tidak sejahtera & $52(43,7)$ \\
Sejahtera & $67(56,3)$ \\
Total & 119 \\
\hline
\end{tabular}

Tabel 3 memperlihatkan bahwa berdasarkan variabel tanggung jawab, 63 responden $(52,9 \%)$ memiliki tanggung jawab yang baik sedangkan 56 responden $(47,1 \%)$ merupakan perawat dan bidan yang memiliki tanggung jawab yang kurang baik.
Tabel 3. Hasil univariat variabel tanggungjawab

\begin{tabular}{lc}
\hline \multicolumn{1}{c}{ Tanggung jawab } & $\mathrm{N}(\%)$ \\
\hline Kurang baik & $56(47,1)$ \\
Baik & $63(52,9)$ \\
Total & 119 \\
\hline
\end{tabular}

Tabel 4 memperlihatkan bahwa berdasarkan variabel motivasi, sejumlah 69 responden $(58 \%)$ perawat dan bidan memiliki motivasi baik sedangkan 50 responden $(42 \%)$ memiliki motivasi kurang baik.

Tabel 4. Hasil univariat variabel motivasi

\begin{tabular}{lc}
\hline \multicolumn{1}{c}{ Motivasi } & $\mathrm{N}(\%)$ \\
\hline Kurang baik & $50(42)$ \\
Baik & $69(58)$ \\
Total & 119 \\
\hline
\end{tabular}

Tabel 5 memperlihatkan bahwa berdasarkan variabel kepuasan kerja sebanyak 65 responden $(54,6 \%)$ merasa puas dengan pekerjaannya sedangkan yang merasa tidak puas sebanyak 54 responden $(45,4 \%)$.

Tabel 5. Distribusi frekuensi variabel kepuasan kerja

\begin{tabular}{lc}
\hline $\begin{array}{c}\text { Kepuasan kerja } \\
\text { perawat dan bidan }\end{array}$ & $\mathrm{N}(\%)$ \\
\hline Tidak puas & $54(45,4)$ \\
Puas & $65(54,6)$ \\
Total & 119 \\
\hline
\end{tabular}

Tabel 6 memperlihatkan hasil uji koefisien regresi secara parsial (uji t) dengan menampilkan nilai t-hitung setiap variabel. Untuk pengaruh kesejahteraan/pendapatan terhadap kepuasan kerja diperoleh nilai thitung sebesar 3,693 dengan nilai signifikansi sebesar 0,000. Hal ini menunjukkan bahwa nilai t-hitung lebih besar daripada nilai t-tabel 1,982 dan nilai signifikansi lebih kecil daripada 0,05 yang berarti bahwa kesejahteraan/pendapatan mempunyai pengaruh bermakna terhadap kepuasan kerja. Untuk pengaruh tanggung jawab terhadap kepuasan kerja diperoleh nilai t-hitung sebesar 0,818 dengan nilai signifikansi 0,415. 
Tabel 6. Uji koefisien regresi secara parsial (Uji T)

\begin{tabular}{lccccc}
\hline & \multicolumn{2}{c}{$\begin{array}{c}\text { Unstandardized } \\
\text { coefficients }\end{array}$} & \multicolumn{2}{c}{$\begin{array}{c}\text { Standardized } \\
\text { coefficients }\end{array}$} \\
Model & $\mathrm{B}$ & Std.Error & Beta & $\mathrm{T}$ & Sig. \\
\hline 1(Constant) & 34,461 & 13,571 & & 2,539 & 0,012 \\
Kesejahteraan/pendapatan (X1) & 0,539 & 0,146 & 0,326 & 3,693 & 0,000 \\
$\begin{array}{l}\text { Tanggung jawab (X2) } \\
\text { Motivasi (X3) }\end{array}$ & 0,289 & 0,321 & 0,083 & 0,898 & 0,371 \\
$\begin{array}{l}\text { Dependent variable: Kepuasan } \\
\text { kerja (Y) }\end{array}$ & 0,202 & 0,246 & 0,075 & 0,818 & 0,415 \\
\hline
\end{tabular}

Hal ini menunjukkan bahwa nilai t-hitung lebih kecil daripada nilai t-tabel 1,982 dan nilai signifikansi lebih besar daripada 0,05 yang berarti bahwa tanggung jawab tidak berpengaruh terhadap kepuasan kerja. Untuk pengaruh motivasi terhadap kepuasan kerja diperoleh nilai t-hitung sebesar 0,898 dengan nilai signifikansi sebesar 0,371 . Hal ini menunjukkan bahwa nilai t-hitung lebih kecil daripada nilai t-tabel 1,982 dan nilai signifikansi lebih besar daripada 0,05 yang berarti motivasi tidak berpengaruh terhadap kepuasan kerja.

\section{BAHASAN}

Hasil penelitian ini mendapatkan 119 responden yang merupakan perawat dan bidan di RSU GMIBM Monompia Kotamobagu. Responden terbanyak pada kelompok usia 26-35 tahun yang berjumlah 84 orang $(70,6 \%)$. Ghiselli dan Brown ${ }^{7}$ melaporkan adanya hubungan antara usia dengan kepuasan kerja. Selain itu usia 25-34 tahun dan usia 40-45 tahun merupakan kelompok responden yang dapat menunjukkan perasaan kurang puas terhadap pekerjaan.

Penelitian ini didominasi oleh responden dengan pendidikan D3 Keperawatan sebanyak 86 responden (72,3\%). Responden dengan pendidikan S1 Keperawatan/Ners ialah yang terbanyak kedua dengan jumlah 21 orang $(17,6 \%)$, diikuti oleh responden dengan pendidikan D3 Kebidanan dengan jumlah 9 orang $(7,6 \%)$, dan pendidikan D4 Kebidanan dengan jumlah 3 orang $(2,5 \%)$. Penelitian yang dilakukan oleh Aulia dan Sasmita ${ }^{8}$ menyatakan bahwa tingginya tingkat pendidikan dan pelatihan mampu meningkatkan kinerja perawat yang akan membawa pengaruh sangat positif dalam kepuasan bekerja.

Pada penelitian ini didapatkan sebagian besar responden berjenis kelamin perempuan yaitu 110 orang $(92,4 \%)$ sedangkan responden berjenis kelamin laki-laki berjumlah 9 orang $(7,6 \%)$. Rizal ${ }^{9}$ menyatakan bahwa perempuan dapat lebih merasa cepat puas dalam melakukan pekerjaan dibandingkan laki-laki dikarenakan adanya perbedaan psikologis antara kedua jenis kelamin. Selain itu, laki-laki mempunyai beban tanggungan lebih besar dibandingkan perempuan, sehingga laki-laki akan menuntut kondisi kerja yang lebih baik seperti gaji yang memadai dan tunjangan karyawan.

Sebagian besar responden memiliki lama kerja di atas 2 tahun yaitu 85 orang $(71,4 \%)$, diikuti oleh responden yang bekerja lebih dari 4 tahun sebanyak 16 orang $(13,4 \%)$, lama kerja di atas 5 tahun sebanyak 10 orang $(8,4 \%)$, dan lama kerja 6-10 tahun sebanyak 5 orang $(4,2 \%)$. Lama kerja di atas 10 tahun ialah yang paling sedikit sebanyak 3 orang $(2,5 \%)$. Menurut asumsi yang dikemukakan oleh Safira dan Anita, ${ }^{10}$ semakin lama seseorang di tempat yang sama dengan pekerjaan yang sama, akan membuat keahliannya semakin meningkat; hal inilah yang menyebabkan seseorang merasa puas dengan pekerjaannya.

Hasil penelitian ini memperlihatkan bahwa terdapat hubungan antara kesejahteraan dengan kepuasan kerja perawat dan bidan. Sekitar 65 dari 119 responden yang merupakan perawat dan bidan memiliki kesejahteraan lebih dari cukup, sedangkan sekitar 54 responden menyatakan tidak sejahtera dan merasa tidak puas dengan kerja 
mereka. Hal ini juga dapat dilihat pada hasil uji statsitik dengan menggunakan liner berganda yang mendapatkan bahwa variabel kesejahteraan/pendapatan berdampak pada kepuasan kerja perawat dan bidan di RSU GMIBM Monompia Kotamobagu dengan nilai $\mathrm{p}=0,000(<\alpha=0,05)$ dan nilai $\mathrm{t}=3,893$ $>$ nilai t-tabel. Sebagian besar perawat dan bidan di RSU GMIBM Monompia Kotamobagu menyatakan puas dengan kerja mereka karena perawat dan bidan menganggap pihak rumah sakit telah memberikan jaminan masa tua; pihak rumah sakit memberikan promosi jabatan; pihak rumah sakit memberikan gaji yang layak dan seimbang sesuai dengan jenjang pendidikan; serta pihak rumah sakit memberikan status pegawai yang jelas kepada perawat dan bidan. Hasil penelitian ini sejalan dengan penelitian yang dilakukan oleh Winanda ${ }^{4}$ yang menyatakan bahwa faktor kompensasi atau penghasilan merupakan salah satu faktor yang menentukan kepuasan kerja petugas medis, termasuk di dalamnya perawat dan bidan di Puskesmas Kota Padang. Kompensasi yang diberikan pihak rumah sakit harus sesuai dengan beban kerja perawat dan bidan. ${ }^{4}$

Kepuasan kerja karyawan menjadi suatu hal penting dan harus dibarengi dengan tingkat kesejahteraan/pendapatan yang sesuai. Sesuai dengan yang dikatakan oleh Sandhar ${ }^{11}$ bahwa kepuasan kerja mempunyai hubungan negatif terhadap intensitas turnover. Artinya, semakin tinggi kepuasan kerja karyawan maka semakin rendah jumlah individu yang memutuskan keluar dari pekerjaannya. Selain itu, kepuasan kerja dapat meningkatkan kualitas pelayanan.

Hasil penelitian ini memperlihatkan bahwa tidak terdapat hubungan antara tanggung jawab dengan kepuasan kerja. Menurut asumsi penulis, hal ini disebabkan karena beberapa responden memiliki tanggung jawab kurang baik sehingga tidak puas terhadap kerja yang dilakukan. Walaupun demikian terdapat juga perawat dan bidan dengan tanggung jawab yang baik sehingga mereka merasa puas atas kerja yang dilakukannya. Hasil olahan data menunjukkan bahwa sebagian besar responden mempunyai tanggung jawab yang baik terhadap kepuasan kinerja yaitu 52,9\% namun tanggung jawab yang kurang baik dengan ketidakpuasan kinerja perawat dan bidan masih didapatkan pada $43 \%$ responden. Hasil uji statistik linear berganda menunjukkan tanggung jawab tidak memengaruhi kepuasan kerja dengan nilai $\mathrm{p}=0,371(<\alpha=0,05)$ serta nilai $\mathrm{t}=0,898$.

Dimyati dan Mudjiono ${ }^{12}$ menyatakan bahwa tanggung jawab adalah sikap yang berkaitan dengan janji atau tuntutan terhadap hak, tugas, kewajiban sesuai dengan aturan, nilai, norma, dan adat-istiadat yang dianut warga masyarakat. Selain itu Burhnudin ${ }^{13}$ menjelaskan bahwa, tanggung jawab adalah kesanggupan untuk menetapkan sikap terhadap suatu perbuatan yang diemban dan kesanggupan untuk memikul risiko dari sesuatu perbuatan yang dilakukan. Berdasarkan kedua pengertian ini maka dapat disimpulkan bahwa tanggung jawab tidak hanya dapat dilakukan oleh pihak pekerja melainkan juga harus disertai adanya tanggung jawab atau komitmen dari pihak rumah sakit. Hussain dan $\mathrm{Asif}^{14}$ di Pakistan menyatakan bahwa komitmen organisasi memberikan dukungan negatif terhadap intensi turnover. Komitmen organisasi merupakan kunci dari faktor yang membuat seorang karyawan tetap bertahan dan merasa puas dalam bekerja pada perusahaan dalam waktu yang lama.

Hasil penelitian ini mendapatkan bahwa motivasi yang rendah memberikan dampak ketidakpuasaan kerja sebesar $42 \%$ dari responden, sebaliknya motivasi yang tinggi memberikan dampak kepuasan kerja sebesar $58 \%$ dari responden. Hasil uji linear berganda menunjukkan bahwa motivasi tidak memengaruhi kepuasan kerja dengan nilai $\mathrm{p}=0,415(<\alpha=0,05)$ serta nilai $\mathrm{t}=0,818$ yang lebih kecil daripada t-tabel. Hal ini tidak sejalan dengan penelitian yang dilakukan oleh Sumartyawati ${ }^{15}$ yang mendapatkan adanya hubungan positif kuat antara motivasi dan kepuasan kerja perawat dengan nilai $\mathrm{r}=0,734$ dan $\mathrm{p}=0,000$. Peneliti berasumsi bahwa hal ini disebabkan karena terdapat faktor-faktor lain yang dapat menyebabkan ketidakpuasan dalam kerja. Motivasi yang 
rendah dari pimpinan akan berdampak negatif terhadap kinerja seseorang, sebaliknya motivasi yang tinggi dari pimpinan dalam suatu institusi akan berpengaruh positif terhadap kinerja seseorang. Faktor lain yang memengaruhi kepuasan kerja ialah faktor motivasi dari karyawan itu sendiri. Faktor motivasi dalam mencapai kepuasan kerja dipengaruhi oleh fungsi manajer. Gaya kepemimpinan akan memengaruhi sikap atasan dalam kepemimpinannya. Atasan atau pimpinan rumah sakit perlu melakukan evaluasi terhadap penyelesaian tugas yang bersifat rasional dan objektif untuk dapat memenuhiharapan dan tuntutan organisasi. Evaluasi tersebut merupakan umpan balik yang sering dirasakan perlu oleh karyawan, sehingga pekerjaan yang dilakukan oleh karyawan tidak hanya dianggap sebagai rutinitas saja. Karyawan akan terus meningkatkan kemampuannya dengan belajar dan berpikir mengenai hal-hal baru dalam memberikan pelayanan keperawatan.

Motivasi menentukan tinggi rendahnya prestasi kerja. Prestasi kerja menghasilkan imbalan (dinilai atau tidak) yang menentukan tinggi rendahnya kepuasan kerja. Kepuasan kerja merupakan hasil dari perbedaan antara imbalan yang dianggap pantas (yang diharapkan) dengan imbalan yang diperoleh. ${ }^{16}$

\section{SIMPULAN}

Kesejahteraan/pendapatan mempunyai pengaruh bermakna terhadap kepuasan kerja perawat dan bidan sedangkan tanggung jawab dan motivasi tidak mempunyai pengaruh terhadap kepuasan kerja perawat dan bidan.

Disarankan bagi pihak rumah sakit agar lebih memperhatikan kesejahteraan pegawai, memberikan motivasi, serta melakukan penilaian tanggung jawab sehingga dapat meningkatkan kepuasan kerja yang berimbas pada mutu pelayanan rumah sakit yang berkualitas.

\section{Konflik Kepentingan}

Penulis menyatakan tidak terdapat konflik kepentingan dalam studi ini.

\section{DAFTAR PUSTAKA}

1. Undang-undang No. 36 Tahun 2014 tentang tenaga kesehatan. Available from https://ktki.kemkes.go.id/info/sites/defa ult/files/UU\%20Nomor\%2036\%20Tah un\%202014\%20tentang\%20Tenaga\%2 OKesehatan.pdf

2. Wolo PD, Trisnawati R, Wiyadi. Faktor-faktor yang mempengaruhi kepuasan kerja perawat pada RSUD TNI AU Yogyakarta. Daya Saing. 2015;17(2): 25-34.

3. Melo MB, Barbosa MA, Souza PR. Job satisfaction of nursing staff: Integrative review. Revista Latino-Americana de Enfermagem. 2011;19(4):1047-55.

4. Winanda, Nindrea RD. Analisis faktor-faktor yang berhubungan dengan kepuasan kerja tenaga medis di puskesmas. Jurnal Endurance. 2017;2(3):333-45.

5. Wijono S. Psikologi Industri dan Organisasi. Jakarta: Kencana, 2010.

6. Riyanto A. Aplikasi Metodologi Penelitian Kesehatan Dilengkapi Contoh Kuesioner dan Laporan Penelitian. Yogyakarta: Nuha Medika,2019.

7. Ghiselli EE, Brown CW. Personnel and Industrial Psychology. Tokyo: McGraw Hill Kogakusha Co, 1955.

8. Aulia R, Sasmita J. Pengaruh pendidikan dan pelatihan kepuasan kerja dan kepemimpinan terhadap kinerja perawat rawat inap di RSUD Kabupaten Siak. Jurnal Tepak Manajemen Bisnis. 2014; 6(2):65-71.

9. Rizal F. Faktor-faktor yang berhubungan dengan kepuasan kerja pegawai Dinas Kesehatan Kotamadya Jakarta Barat tahun 2004 [Tesis]. Jakarta: Universitas Respati Indonesia; 2005.

10. Shafira AL. Perbedaan kepuasan kerja pada karyawan berdasarkan usia dan masa kerja. Jurnal Empati. 2017;6(1):396-400.

11. Sandhar SK. A relationship between job satisfaction and turnover intention in information technology sector. Pezzottaite Jounals. 2014;4(3):1521-31.

12. Dimyati, Mudjiono. Evaluasi Pembelajaran. Bandung: PT Remaja Rosdakaya, 2012.

13. Burhanudin. Perilaku Organisasional. Yogyakarta: CAPS, 2011

14. Hussain T, Asif S. Is employees' turnover intention driven by organizational commitment and perceived organizational support? Journal of Quality and Technology Management. 2012;VIII(II):1-10. 
15. Sumartyawati NM. Hubungan motivasi dengan kepuasan kerja perawat di ruang rawat inap RSJ Provinsi NTB. PrimA. 2017;3(1):8-14.

16. Sania R. Pengaruh motivasi dan reward terhadap kepuasan kerja karyawan bagian office (non medis) Rumah Sakit Bogor Medical Center [Abstrak]. Universitas Indonesia Library Available from http://lib.ui.ac.id/file?file=digital/ 20321155-S-Ratu\%20Sania.pdf 